\title{
Penilaian kualitas kortikal mandibula pasien diabetes mellitus tipe 2 dengan analisis radiomorfometrik pada radiograf panoramik
}

\author{
Annisa Putri ${ }^{*}$, Aga Satria Nurrachman', Lusi Epsilawati ${ }^{2}$, Azhari $^{2}$
}

\begin{abstract}
Objectives: This research aims to evaluate patients, both have dominant result of $\mathrm{MCl}$ radiological finding on bone of patients with T2DM assessment type C2. While the result of Antegonial (type 2 Diabetes Mellitus) by evaluating mandibular Index assessment there were a difference of cortical cortical quality using radiomorphometric thickness between two groups. The average Al value assessment specifically $\mathrm{MCl}$ (Mandibular Cortical from normal patients were 4,179 with standard Index) and Al (Antegonial Index).

Material and Methods: This research is a descriptive analytic cross-sectional study, Conclusion: Based on the results of the study, it was populations and samples using secondary data found that there has been a significance difference radiographs of T2DM patients that have been of cortical bone qualities between two groups of proven by medical statement from a doctor and samples which can be seen from the result of normal sample were selected according to specified Antegonial Index, a T2DM patients has average criterias.

Results: It showed between group consisting of patients with T2DM and another one with normal values lower than normal patients, while for the results of $\mathrm{MCl}$ assessment between two groups have similar types.
\end{abstract}

Keywords: Diabetes mellitus, panoramic radiographs, mandibular cortical index, antegonial index Cite this article: Putri A, Nurrachman AS, Epsilawati L, Azhari A. Penilaian kualitas kortikal mandibula pasien diabetes mellitus tipe 2 dengan analisis radiomorfometrik pada radiograf panoramik. Jurnal Radiologi Dentomaksilofasial Indonesia 2020;4(1)23-6. https://doi.org/10.32793/jrdi.v4i1.463

${ }^{1}$ PPDGS Radiologi Kedokteran Gigi, Fakultas Kedokteran Gigi, Universitas Padjadjaran, Bandung, Indonesia, 40132

2 Departemen Radiologi Kedokteran Gigi, Fakultas Kedokteran Gigi, Universitas Padjadjaran, Bandung, Indonesia, 40132

*Correspondence to:

Annisa Putri

凹annisa.putri@iik.ac.id

Received on: February 2020

Revised on: March 2020

Accepted on: April 2020

\section{PENDAHULUAN}

Diabetes mellitus (DM) merupakan salah satu penyakit yang sering terjadi di seluruh dunia. Penyakit ini dapat diakibatkan oleh defisiensi insulin karena adanya kerusakan sel beta pankreas (DM tipe 1) atau keadaan resistensi insulin (DM tipe 2). Keadaan hiperglikemia atau kadar gula darah yang tinggi merupakan karakteristik utama pada kedua tipe diabetes. ${ }^{1}$ Kondisi tersebut secara tidak langsung juga mengakibatkan hypercalciuria yang menyebabkan penurunan level kalsium tubuh sehingga kualitas tulang menurun. Selain itu DM secara umum menyebabkan komplikasi microvaskular yang menggangu proses laju aliran darah dan diketahui berkontribusi pada transportasi nutrisi pada tulang yang terganggu sehingga terjadi kerusakan fungsi tulang. ${ }^{2}$

Hingga saat ini variable assessment kualitas tulang yang menjadi gold standard adalah pemeriksaan BMD (bone mineral density) menggunakan Dual-Energy X-ray Absorptiometry (DEXA). Namun penggunaan DEXA sebagai diagnostic tool masih terbatas karena biaya operasional yang tidak murah sehingga belum menjangkau semua kalangan. Dalam beberapa literatur disebutkan bahwa pada kasus penurunan
BMD di skeletal secara langsung juga akan mempengaruhi kualitas tulang di mandibula. Radiograf Panoramik merupakan salah satu tindakan radiografi yang rutin dan sering dilakukan oleh klinisi, selain dapat digunakan sebagai pemeriksaan penunjang radiograf panoramik juga dapat dimanfaatkan sebagai screening tool dalam menganalisis kualitas tulang. ${ }^{3}$

Analisis radiomorfometrik merupakan salah satu analisis yang banyak dipilih dan diterapkan oleh banyak peneliti dalam menilai kualitas tulang, baik secara kualitatif dan kuantitatif. Salah satu penilaian kualitatif ialah menggunakan metode Klementti atau yang lebih dikenal dengan indeks $\mathrm{MCl}$ (Mandibular Cortical Index), dimana penilaian dilakukan secara visual dengan mengklasifikasikan korteks mandibula ke dalam beberapa kategori sesuai dengan morfologinya. Selain itu terdapat beberapa penilaian kuantitatif, salah satunya merupakan indeks Al (Antegonial Index) yang mengukur ketebalan kortikal pada daerah anterior gonion. Kedua parameter ini telah banyak digunakan dalam menilai kualitas dan tanda resorpsi tulang, dimana telah dibuktikan mempunyai korelasi yang erat dengan BMD 
skeletal, yang dapat menggambarkan keadaan osteoporosis. $^{1,4-7}$

Berdasarkan informasi dari penelitian terlebih dahulu dijelaskan bahwa gambaran tulang mandibula yang terlihat pada radiograf panoramic dapat membantu sebagai salah satu assessment penilaian kualitas tulang. Penelitian ini bertujuan untuk memberikan gambaran mengenai kondisi tulang pada penderita diabetes mellitus tipe 2 melalui penilaian kualitas tulang kortikal mandibula dengan menggunakan analisa morfometrik metode $\mathrm{MCl}$ dan Al.

\section{BAHAN DAN METODE}

Penelitian ini merupakan penelitian deskripsi analitik, dengan pendekatan cross-sectional. Populasi dan sampel yang digunakan adalah data sekunder dari radiograf panoramik kelompok normal sebanyak 25 orang dan pasien DM tipe 2 sebanyak 25 orang yang telah dibuktikan dengan surat keterangan dari dokter. Adapun sampel yang terpilih adalah semua radiograf yang memenuhi kriteria berikut: 1) pasien penderita DM tipe 2 minimal 1 tahun, 2) data radiografi berkualitas baik sehingga dapat dilakukan penilaian. Dalam penelitian ini, usia dan jenis kelamin termasuk dalam kriteria eksklusi. Penelitian ini telah mendapatkan persetujuan dari Komite Etik Penelitian Kesehatan Universitas Padjadjaran Bandung dimana studi ini dilakukan. Selain itu sebagai kelompok normal dilakukan pemeriksaan pada pasien dengan usia yang sama pada kelompok tanpa penyakit sistemik.
Variabel yang dinilai adalah kualitas tulang kortikal mandibula dengan cara mengukur ketebalan tulang menggunakan metode Mandibular Cortical Index $(\mathrm{MCl})$. Penilaian dilakukan secara visual dengan mengklasifikasikan bentuk morfologi korteks inferior mandibula sepanjang foramen mentalis hingga regio antegonial ke dalam tiga kategori: C1, margin endosteal dari korteks terlihat tajam dan tegas pada kedua sisi, menandakan bahwa korteks dalam kondisi normal dan tidak terjadi perubahan; C2, margin endosteal memiliki defek semilunar atau membentuk residu (satu hingga tiga lapisan) pada satu atau kedua sisi (mild to moderately eroded cortex); C3, lapisan kortikal membentuk endosteal dengan residu yang lebih tebal dan berporus dengan ketebalan yang berkurang (severely eroded cortex). ${ }^{8,9,10}$

Pengukuran ketebalan kortikal mandibula menggunakan Antegonial Index dilakukan pada area yang terletak pada anterior sudut gonial, yakni berupa garis yang tegak lurus terhadap korteks pada garis yang menghubungkan batas anterior dar ramus ascendens hingga batas bawah mandibula. Pengukuran dilakukan pada sisi kanan dan kiri mandibular, yang kemudian diambil nilai rata-rata sebagai hasil akhir menggunakan software Image-J (National Institute of Health, Bethesda, MD, USA). ${ }^{11}$ Data yang terkumpul kemudian dianalisis dengan aplikasi Statistical Package for the Social Sciences (SPSS for Windows, version 21.0, IBM Inc, Amonk, NY, USA). Antegonial Index kelompok normal dengan kelompok DM tipe 2 dilakukan uji beda chisquare untuk melihat hubungan signifikansi variabelnya.
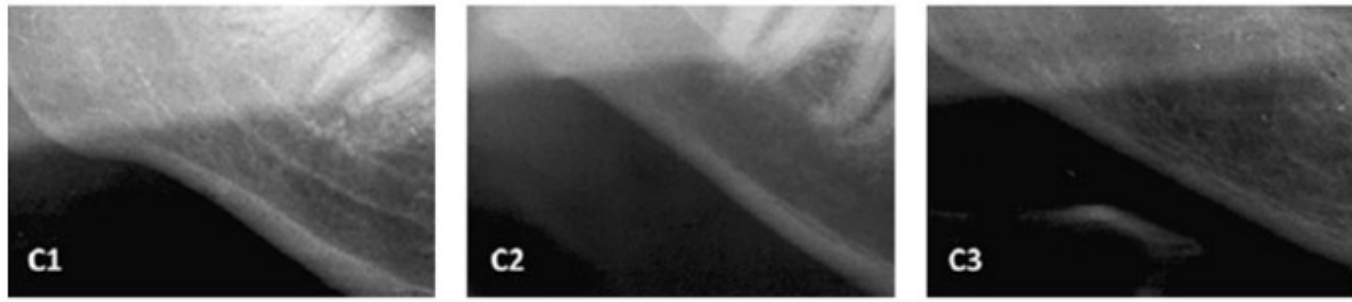

Gambar 1. Kategori bentuk morfologi kortikal pada penilaian $\mathrm{MCl}^{8}$

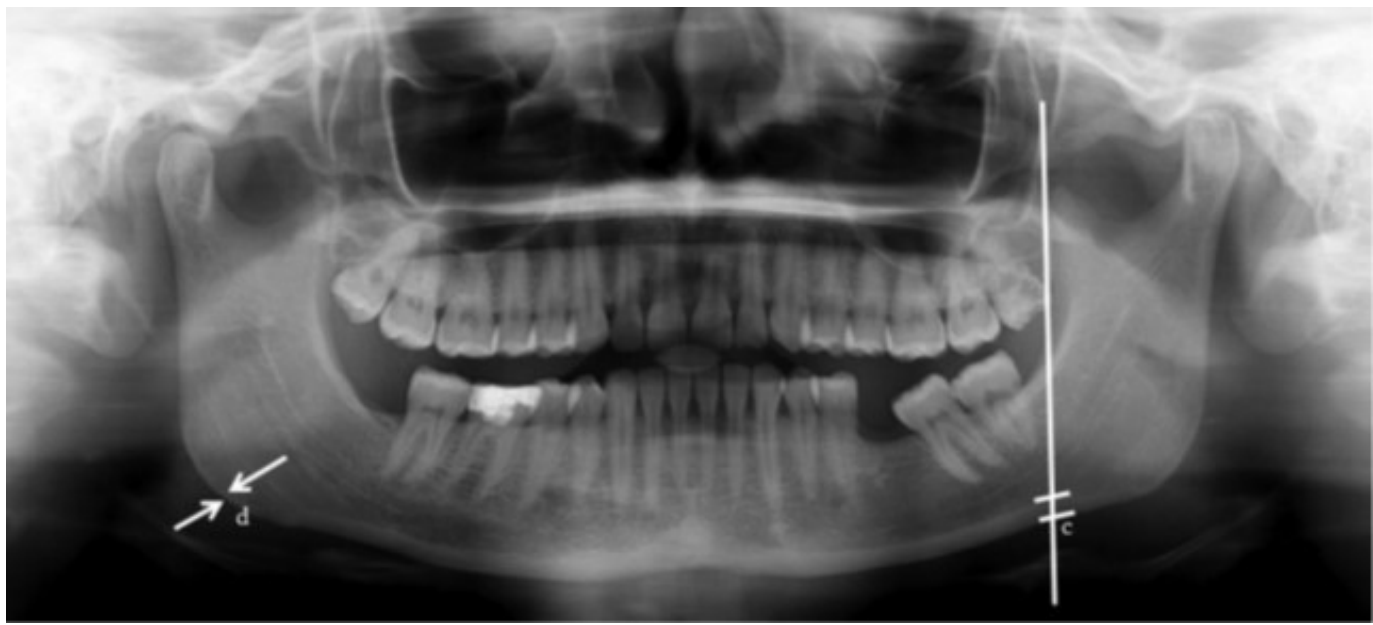

Gambar 2. Area pengukuran Al pada radiograf panoramik ditandai oleh garis $C^{9}$ 
HASIL

Penelitian ini dilakukan terhadap 50 radiograf panoramik yang telah dikumpulkan sesuai kriteria yaitu 25 radiograf panoramik kelompok normal dan 25 radiograf panoramik kelompok pasien DM tipe 2 . Hasil penelitian menunjukkan bahwa kualitas tulang kortikal mandibular yang dinilai dengan Mandibular Cortical Index kedua kelompok sampel mempunyai tipe C2 (mild to moderately eroded cortex) yang dominan.

Pada kelompok normal sebanyak $68 \%$ dari total sampel kelompok tersebut didapatkan hasil tipe C2, sedangkan 32\% lainnya memiliki tipe C1. Pada kelompok pasien DM tipe 2 sebanyak $56 \%$ dar total sampel kelompok tersebut memiliki tipe C2, sedangkan $8 \%$ lainnya terdapat variasi tipe C3 (severely eroded cortex). Distribusi tersebut dapat dilihat pada tabel berikut.

Evaluasi ketebalan tulang kortikal mandibular dinilai menggunakan Antegonial Index pada sis kanan dan kiri, didapatkan hasil bahwa terdapat perbedaan antara rata-rata perhitungan Al pada kelompok normal dengan kelompok pasien DM tipe 2. Pada kelompok normal, nilai Al rata-rata adalah 4.179 dengan nilai terendah 3.451 dan tertinggi mencapai 5.068. Sedangkan pada kelompok pasien DM tipe 2, nilai rata-rata $\mathrm{Al}$ lebih rendah dar kelompok kontrol yaitu sebesar 3.641. Pada kelompok tersebut, nilai terendah Al 2.692 dan tertinggi 4.571. Sebaran data hasil perhitungan A terhadap kedua kelompok dapat dilihat pada table berikut.

Berdasarkan hasil uji normalitas dengan Shapiro-Wilk didapatkan data berdistribusi normal dengan $p>0.05$, pengujian dengan uji beda chisquare menunjukkan terdapat perbedaan yang signifikan pada perhitungan Antegonial Index antara kelompok pasien normal dengan kelompok pasien DM tipe 2

\section{DISKUSI}

Diabetes Mellitus merupakan penyakit yang membutuhkan perawatan jangka panjang Kesehatan tulang merupakan hal yang patu diperhatikan secara berkala pada penderita DM Baik DM tipe 1 ataupun 2 berkaitan erat dengan meningkatnya risiko fraktur pada tulang meski melalui mekanisme yang kemungkinan berbeda. Berbagai literatur menjabarkan bukti bahwa DM dapat menjadi sebuah faktor risiko terjadinya fraktur osteoporosis. Terlepas dari banyaknya data efek DM terhadap tulang yang ada, banyak hasil antara satu penelitian dengan penelitian yang lain yang kontradiktif. Hal ini dapat terjadi dikarenakan patofisiologi DM yang rumit, macam area skeletal yang diperiksa, teknik yang berbeda untuk menilai densitas tulang, perbedaan durasi, keparahan dan perawatan yang terima. ${ }^{1}$

Radiografi panoramik merupakan pemeriksaan yang sering dipilih para praktisi dalam mendiagnosa dan screening keadaan gigi. Terdapat beberapa penelitian yang menjabarkan kegunaan radiograf panoramik sebagai alat untuk menilai tanda-tanda resorpsi dan osteoporosis. Berdasarkan kualitas tulang dalam sebuah radiograf panoramik, terdapat beberapa indeks yang dapat digunakan seperti MC dan Al. Banyak penelitian sebelumnya telah membuktikan representasi hasil perhitungan radiomorfometrik dalam hubungannya dengan BMD yang rendah. ${ }^{1}$

Dari penelitian ini didapatkan hasil bahwa pada

Tabel 1. Frekuensi tipe Mandibular Cortical Index ( $\mathrm{MCl}$ ) pada kedua kelompok penelitian

\begin{tabular}{|c|c|c|c|c|c|}
\hline & & \multicolumn{3}{|c|}{$\mathrm{MCl}$} & \multirow[t]{2}{*}{ All } \\
\hline & & $\mathrm{C} 1$ & $\mathrm{C} 2$ & $\mathrm{C} 3$ & \\
\hline \multirow[t]{2}{*}{ Kelompok normal } & Jumlah & 8 & 17 & 0 & 25 \\
\hline & Persentase & 32 & 68 & 0 & 100.0 \\
\hline \multirow[t]{2}{*}{ Kelompok DM tipe 2} & Jumlah & 9 & 14 & 2 & 25 \\
\hline & Persentase & 36 & 56 & 8 & 100.0 \\
\hline \multirow[t]{2}{*}{$A / l$} & Jumlah & 17 & 31 & 2 & 50 \\
\hline & Persentase & 34 & 62 & 4 & 100.0 \\
\hline
\end{tabular}

Tabel 2. Hasil perhitungan Antegonial Index (AI) pada kedua kelompok penelitian

\begin{tabular}{lcccccc}
\hline & Rata-rata & SD & Minimum & Maximum & $t$ & $p$ \\
\hline Kelompok normal & 4.179 & 0.420 & 3.451 & 5.068 & & \\
\hline Kelompok DM tipe 2 & 3.641 & 0.477 & 2.692 & 4.517 & 0.05 \\
\hline
\end{tabular}


kedua kelompok sampel hasil analisis Mandibular Cortical Index dominan C2 (mild to moderately eroded cortex). Hal tersebut bisa disebabkan karena analisis $\mathrm{MCl}$ dilakukan dengan pemeriksaan visual sehingga dalam menyimpulkan kasus bisa terjad bias antara satu pengamat dengan pengamat yang lain, berkaitan dengan sensitivitas dan proper training yang berbeda pada tiap individu pengamat dalam menganalisa hasil foto. ${ }^{10}$ Selain itu terbatasnya jumlah sampel yang digunakan pada penelitian ini menyebabkan hasil penelitian tidak terdapat perbedaan yang signifikan. Penelitian oleh Munhos menyatakan bahwa usia, jenis kelamin dan status gigi geligi ikut berperan dalam menentukan kualitas tulang kortikal mandibular, kriteria ini tidak diperhitungkan pada penelitian ini. ${ }^{12}$ Pada penelitian ini juga tidak dievalusi kadar HbAlc pada kelompok DM tipe 2 karena menurut penelitian oleh Jolly pada pasien DM tipe 2 yang terkontrol kadar HbA1c-nya berada antara 6.1-8\% menunjukan level BMD yang sama baiknya dengan kelompok pasien non-diabetes. Glycemic level yang terkontrol menurut kualitas tulang masih dapat terjaga. ${ }^{13}$

Terdapat variasi hasil penilaian $\mathrm{MCl}$ yaitu tipe $\mathrm{C} 3$ (severely eroded cortex) pada kelompok pasien DM tipe 2 yang tidak ditemukan pada kelompok normal. Hal ini sejalan dengan penelitian oleh Starrup-Linde bahwa pada kondisi resistensi insulin, aktivitas osteoklastik ditemukan lebih tinggi yang menyebabkan resopsi tulang terjadi lebih cepat. Pada kondisi hiperglikemia juga menunjukkan penurunan $\mathrm{OCN}^{+}$cells yang merupakan precursor histomorfometrik tulang merusak aktivitas dan kelangsungan hidup osteoblas. ${ }^{14}$

Hasil pengukuran Antegonial Index diperoleh hasil bahwa terdapat perbedaan antara kelompok normal dengan rata-rata 4.179 dan kelompok pasien DM tipe 2 rata-rata 3.641. Ini menunjukkan bahwa pada pasien DM tipe 2 telah terjadi penurunan densitas tulang walaupun belum terlihat secara jelas. Kondisi hiperglikemia menyebabkan diferensiasi osteoblas menurun dengan mengganggu kinerja osteoprotegerin dan meningkatan diferensiasi osteoclastogenesis sehingga maturasi osteoklas berjalan lebih cepat. Proses resopsi dan aposisi tidak berjalan seimbang sehingga merusak dinamika proses sekres RANKL (Receptor activator of nuclear factor kappa$B$ ligand). Jika berjalan terus menerus proses ini menyebabkan penyerapan mineral yang diperlukan tulang seperti kalsium terhambat dan akan mempengaruhi kerapatan antar matriks pada tulang. ${ }^{15}$

\section{SIMPULAN}

Berdasarkan hasil penelitian diperoleh hasil bahwa terdapat perbedaan signifikan dalam kualitas tulang kortikal antara kelompok normal dan kelompok DM tipe 2 terutama pada metode Antegonial Index.

\section{DAFTAR PUSTAKA}

1. Varma B, David AP, Kurup S, Sam DM, Aravind M, Chandy ML Assessment of Panoramic Radiomorphometric Indices of Mandible in Diabetes Mellitus Patients and Non Diabetic Individuals. J Clin Diagnostic Res. 2017;11(11):35-9.

2. Asokan AG, Jaganathan J, Philip R, Soman RR, Sebastian ST, Pullishery F. Evaluation of Bone Mineral Density among Type 2 Diabetes Mellitus Patients in South Karnataka. J Nat Sci Bio Med. 2017;8(1):94-98.

3. Tofangchiha M, Javadi A. Diagnosis of Osteoporosis using Cortex Mandibular Indices based on Cortex Thickness and Morphology in Comparison with Visual Assessment of the Cortex. J Craniomax Res. 2017; 4(2) :345-351

4. Dagistan S, Bilge OM. Comparison of antegonial index, mental index, panoramic mandibular index and mandibular cortical index values in the panoramic radiographs of normal males and male patients with osteoporosis. Dentomaxillofacial Radiol. 2010;39:290-4.

5. Limeira, Francisco IR, Patrícia RM, Denise N, Patrícia M. Decrease in Mandibular Cortical in Patients With Type 1 Diabetes Mellitus Combined with Poor Glycemic Control. Brazilian Dental Journal. 2017: 28(5), 552-558.

6. Yalcin ED, Avcu N, Uysal S, Arslan U. Evaluation of Radiomorphometric Indices and Bone Findings on Panoramic Images in Patients with Scleroderma. Oral Surg Oral Med Ora Pathol Oral Radiol [Internet]. 2018; Available from: https:// doi.org/10.1016/j.000o.2018.08.007

7. Bajoria AA, MI A, Kamath G, Babshet M, Patil P, Sukhija P. Evaluation of Radiomorphometric Indices in Panoramic Radiograph - A Screening Tool. Open Dent J. 2015;9(Suppl 2: M9):303-10.

8. Ivison $F$, Limeira $R$, Ravena $P$, Rebouças $M$. Decrease in Mandibular Cortical in Patients With Type 1 Diabetes Mellitus Combined with Poor Glycemic Control. Braz Dent J. 2017;28 (5):552-8.

9. Akshita D, Asha V. Reliability of panoramic radiographic indices in identifying osteoporosis among postmenopausal women. J Oral Maxillofac Radiol. 2017;5:35-9.

10. Dagistan S, Miloglu O, Caglayan F. Changes in jawbones of male patients with chronic renal failure on digital panoramic radiographs. Eur J Dent. 2016;10:64-8

11. Schneider, CA, Rasband, WS, Eliceiri, KW. NIH Image to imagej: 25 years of image analysis. Nature methods. 2012; 9 (7): 671-675.

12. Munhoz L, De Arruda CFJ, Mendonça Alves FA, Arita ES, Lourenço SV, Costa C. The use of panoramic radiographs modified by an open access software to determine Mandibular Cortical Index. Rev Odonto Cienc. 2017;32(2):837.

13. Jolly SJ, Hegde C, Shetty NS. Assessment of Maxillary and Mandibular Bone Density in Controlled Type II Diabetes: A Computed Tomography Study. J Oral Implantol. 2015;41:400 5

14. Starup-Linde J, Westberg-Rasmussen S,Lykkeboe $\mathrm{S}$ Vestergaard P. Effects of Glucose on Bone Markers: Overview of Current Knowledge with Focus on Diabetes, Glucose, and Bone Markers. 2015. Diakses dari: http:// link.springer.com/10.1007/978-94-007-7745-3

15. Hastar E, Yilmaz HH, Orhan H. Evaluation of mental index, mandibular cortical index and panoramic mandibular index on dental panoramic radiographs in the elderly. Eur J Dent. 2011;5(1):60-7. 